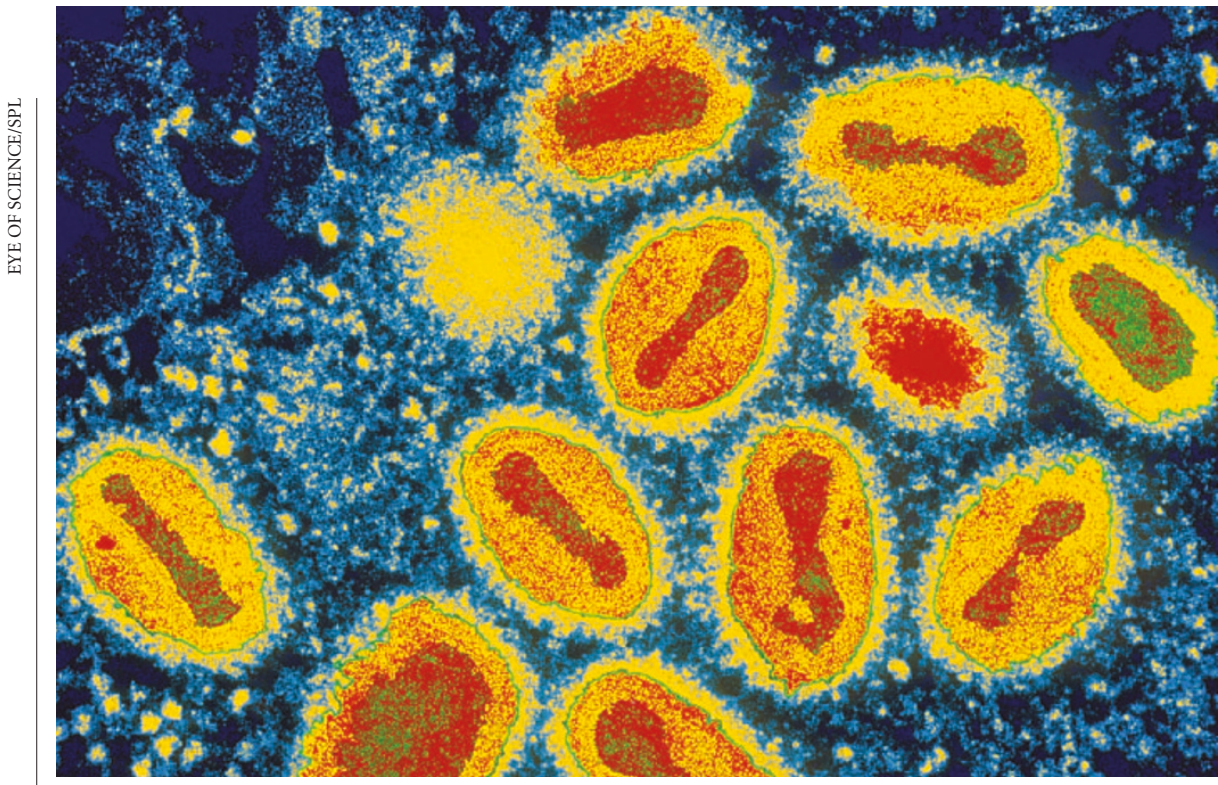

Varying variola: researchers may soon be allowed to add a 'marker gene' to the smallpox virus.

\title{
Unanimous vote approves tweak to smallpox genome
}

\section{Erika Check, Washington}

An influential committee at the World Health Organization (WHO) has voted in favour of modifying genes in the smallpox virus, and in the vaccine strains that eradicated the disease.

If enacted, the recommendations would overturn decades of policy that govern the two remaining samples of the variola virus, which causes smallpox. The samples are kept at the Centers for Disease Control and Prevention (CDC) in Atlanta, Georgia, and at a lab run by the Russian government in Novosibirsk, Siberia.

Scientists have traditionally been wary of allowing these samples to be genetically modified. But on 5 November, the WHO Advisory Committee on Variola Virus Research voted unanimously to permit one specific genetic manipulation of the virus, says WHO spokeswoman Maria Cheng. The members also voted to permit genetic modification of the vaccine strain that eradicated the disease from the globe.

The advisers said that the moves would speed research on smallpox treatments. The committee proposes that researchers be allowed to insert a 'marker gene' into the variola genome, which would make the virus glow green. This would allow scientists to detect quickly whether a potential treatment has killed the virus.

The recommendations will be considered early next year by the WHO's director-general and executive board, and possibly later by the 192-member World Health Assembly.

"The use of a marker gene would permit greater rapidity for things such as screening antivirals, and that in turn would decrease the contact time that researchers have with the virus," says Inger Damon, chief of the
CDC's poxvirus section, who attended the WHO meeting.

The only potential drug treatment for smallpox, an antiviral compound called cidofovir, must be given intravenously, although scientists are trying to develop an oral version. Ideally, researchers would like to have more than one treatment option in case drugresistant smallpox strains emerge naturally or are created by deliberate engineering. The current vaccines against smallpox are also imperfect as they are either inefficient or have potentially life-threatening side-effects.

But the WHO proposals have met with fierce criticism. Jonathan Tucker, a non-proliferation analyst at the Monterey Institute of International Studies in California, says that allowing the modification could give some countries the idea that the United States and Russia are trying to turn smallpox into a more potent bioweapon. "My concern is that this work would break the taboo against genetic engineering of smallpox virus,"Tucker says.

Advisers to the WHO committee point out that they are asking for only one genetic modification, which will not change the virulence of the virus. "What we're asking for is limited in scope," says Bernard Moss, head of the Laboratory of Viral Diseases in Bethesda, Maryland. Moss was a special adviser at the WHO meeting. "These modifications will result in the elimination of variola virus earlier," he says.

But Tucker says that if the work goes ahead, the WHO advisory committee will need to strengthen its supervisory capabilities. "The committee really needs a full-time staff person and more resources if it's going to be expanding the smallpox research programme," Tucker says.
Britain to combat conflicts of interest in drug regulators

Jim Giles, London

Tough measures designed to excise conflicts of interest from committees that regulate drugs have been proposed by the British government.

If the proposals are accepted, advisers on the panels that assess drug safety and performance, and report to the Medicines and Healthcare products Regulatory Agency (MHRA), will have to relinquish all financial interests in the pharmaceutical industry, health minister Norman Warner said on 11 November.

Committee members would also have to declare financial benefits, such as conference costs paid for by industry.

The move comes as pressure mounts on pharmaceutical companies and regulators in Europe and the United States. The MHRA has been the subject of television and newspaper investigations in recent months, which have alleged numerous conflicts of interest on the part of staff and advisers.

In the United States, officials at the Food and Drug Administration (FDA) have been accused of mishandling health scares associated with the painkiller Vioxx (rofecoxib) and a widely used class of antidepressants (see Nature 431, 122-124; 2004). In both cases, critics accused the FDA of acting in the interests of industry rather than patients.

The UK proposals, which are open for consultation until February, meet many of the demands made by patients' rights activists in the wake of these stories. In addition to ruling out direct pharmaceutical interests, members would have to declare relevant interests held by family members. Scientists on the committee would also have to say whether they have done any research relating to a particular product, even if that work was not funded by a pharmaceutical company.

Patients' groups in the United States have welcomed the proposals. "The British regulators are moving in the right direction and opening up the secretive club that binds drug-industry representatives and regulators," says Vera Hassner Sharav of the Alliance for Human Research Protection in New York.

The Association of the British Pharmaceutical Industry insists that the MHRA committees are already impartial, because members do not take part in discussions on drugs in which they have a financial interest. But the association accepts that "justice must not only be done but be seen to be done". 